\title{
Making the threatening Other laughable: Ambiguous performances of urban vernaculars in Swedish media
}

See also:

Jonsson, Rickard, Franzén, Anna \& Milani, Tommaso M. (2020). Making the threatening other laughable: Ambiguousperformances of urban vernaculars in Swedish media, Language \& Communication, 71, 1-15. https://doi.org/10.1016/j.langcom.2019.11.001

\section{Introduction}

Youth speech styles in multilingual settings have been the object of a large body of sociolinguistic inquiry since the early 1980s (see Hewitt, 1982, 1986; Kotsinas, 1988; see also Cheshire et al., 2011; Kern and Selting, 2011; Madsen, Karrebæk and Møller, 2015; Nortier and Svendsen, 2015; Quist and Svendsen, 2010; Wiese, 2012). Rampton (2011, 2015) has recently suggested the umbrella term 'contemporary urban vernaculars' to label these linguistic phenomena in a way that transcends age and ethnicity. After all, contemporary urban vernaculars are not only employed by young people (see in particular Rampton, 2015; Eliaso Magnusson and Stroud, 2012), nor are they spoken by ethnic minorities alone (Årman, 2018). In the Swedish context, the term 'ortensvenska' ('Suburban Swedish') has been used to refer to these linguistic phenomena. Here the Swedish word orten literally means 'suburb' and carries the social class connotation of the American 'project' or the British 'estate'. Another well spread label of the same style, 'Rinkeby Swedish' (Rinkebysvenska), also refers to an urban periphery: the multiethnic and socioeconomically disadvantaged Stockholm suburb of Rinkeby. Most importantly for the purpose of this article, 'Rinkeby' Swedish has been turned by media discourses into an 'icon' (Irvine and Gal, 2000) of ethnic otherness, associated with an aggressively sexist and homophobic masculinity (Author 1, 2007; Author 1 and Author 3, 2009; Author 3, 2010; Author 3 and Author 1, 2012: Stroud, 2004, see also Cornips, Jaspers and Rooij, 2015 for a discussion on labelling of styles). In other words, the threatening young man who speaks Rinkeby Swedish has become a 'figure of personhood' (Agha, 2007, 2011), that is, a culturally recognizable social persona that circulates in mainstream media as well as in political discourse and school contexts (Madsen, Karrebæk and Møller, 2015; Nortier and Svendsen, 2015, Author 3 and Author 1, 2011). 
That being said, figures of personhood are never static but are constantly re-typified (Agha, 2011). Moreover, it should be highlighted that, in the specific case of Rinkeby Swedish, the media in Sweden are prominent discursive sites where such (re-)typifications can be seen to occur and compete with each other. So, in the Swedish media landscape, the speaker of Rinkeby Swedish still evokes moral panic when he - this speaker is iconically embodied by a young man - appears to threaten Sweden's celebrated gender equality and sexual rights. Yet such a threatening figure of personhood can also be the target of laughter and its counterpart, i.e. unlaughter (Billig, 2005; Ahmed, 2010a, 2010b). In this article, we focus specifically on the different usages and meanings of humour in relation to Rinkeby Swedish, and the different facets of the characterological persona that this speech style brings into being.

\section{Laughing at urban vernaculars in 'colour-blind' Sweden}

Our research is inspired by Hill's (1998) work on 'Mock Spanish', in which she argues that the linguistic practices of white American English speakers incorporating Spanish linguistic resources - such as macho, cerveza, or mañana - into their talk create a jocular key that is also pejorative (Hill, 1998: 682; Hill, 2008). While Mock Spanish may be employed to perform a humorous or easy-going persona, Hill argues that the element of fun of this style is always at the expense of Spanish speakers. It therefore works as a type of covert racist discourse (2008:119f). In contrast, Jaspers (2005) takes a less definite position on multilingual humour in an ethnographic investigation of language practices among Moroccan boys in a Belgian school. Detailed analysis illustrates that the humorous use of nonnormative linguistic styles indeed relies on ethnic/racial stereotypes but is simultaneously a strategy through which these young people resist stereotyping identity categories (see also Author 1, 2018).

The performative effect of a joke where contemporary urban vernaculars are used to evoke laughter depends on context, audience, and the question of entitlement (De Fina and Georgakoupolou, 2012). In humour, as Pickering and Lockyer (2005:8-9) state, 'who is comically treated by whom and with what consequences are crucial factors that can determine the outcome of a joke and whether or not it is regarded as offensive'. In order to understand this context-dependent ambiguity, it is important to note that Sweden is a place where overtly racist discourse is frowned upon, and where a colour-blind and anti-racist discourse has become hegemonic in public discourse (Hübinette and Lundström, 2011). Although it is true that right-wing populism has become more accepted in the Swedish political landscape over 
the last decade, such normalization has been expressed in and through an anti-racist discourse (Hübinette and Lundström, 2011, see also Author 1, 2018). Even the largest Swedish populist party with Nazi roots, Sverigedemokraterna (Sweden Democrats), paradoxically advances xenophobic policy positions while claiming 'zero tolerance' towards racism (Ulvenlöv et al., 2017). Needless to say, the hegemonic nature of anti-racist discourse does not mean that race and racism are not present in everyday Swedish life.

It is against this contextual backdrop of an alleged racial colour-blindness that we aim to explore humour about the figure of personhood of the speaker of Rinkeby Swedish (see also Androutsopoulos, 2016 for a case in point in the German context). More specifically, we raise the following research questions: What happens when the figure of personhood of the threatening Rinkeby Swedish speaker become the target of jokes and ridicule in media texts? What does it mean to laugh at speakers of Rinkeby Swedish within a Swedish discursive regime where overt racist and xenophobic utterances are frowned upon? And what subversive, as well as repressive, potentials reside in laughter evoked in contexts where contemporary urban vernaculars are spoken? We answer these questions with the help of Billig's (2005) conceptualization of laughter and ridicule. It is to such a theoretical framework that we will now turn.

\section{Humour and stylizations as discursive practices}

As Chun (2013) cogently puts it, humour 'is an ideal space for engaging in ideological work, given that humorous performers have license to break with everyday norms of interaction' ( $p$. 278). To analyse humorous spaces, we draw upon Billig's (2005) theorization of humour, and especially ridicule, as intrinsically tied to the social order, constituting a fundamental social force. Sociologists and social psychologists (for instance, Berger, 2014; Goffman, 1967; Hay, 2000) have often understood humour as something that ties people together, creating rapport so that when we laugh, we laugh with each other. If someone has breached a social norm (faux pas), for example, laughing is a way of saving face (see Goffman, 1967). Billig, however, takes aim at what he calls 'ideological positivism', that is, the theoretical impulse to see the pleasant side of humour, and points out that we also laugh at those who make fools of themselves, while taking pleasure in the breaching of norms. He argues that ridicule in fact reproduces social norms, structuring much of our social life. By laughing at each other when norms are breached, we can both enjoy the temporary respite from the rule, and discipline each other into following it in future. Put differently, humour works through ambivalence. It can be disciplinary or repressive when it mocks the non-normative, but it can also be 
rebellious when it mocks the norms themselves, or those who hold powerful positions in a social hierarchy. This latter type of humour may have the potential of disrupting the existing order, but Billig (2005) reminds us that what appears to be rebellious may simultaneously have a covertly conservative role:

At times, rebellious humour - or humour that is claimed and experienced as rebellious can have conservative and disciplinary functions. Far from subverting the serious world of power, the humour can strengthen it [...] The more we laugh and the more we imagine ourselves to be daringly free in the moments of our laughter [...] the more we reveal ourselves captive to the demand that we possess as humour. (Billig, 2005:212).

Following Billig, we do not understand humour as necessarily liberating or morally good, nor as something outside power and social order. On the contrary, social life is played out through jocular practices, in both its subversive and repressive forms. Humour is serious business; it is rhetorical, and reality is constructed through such discursive jocular work. Most crucially, the possibility of laughter exists because we also have the option of not laughing. Both options construct meaning and work as discursive-rhetoric moves (Billig, 2005). It is therefore also relevant to explore unlaughter - an absence of laughter in a context where laughter might have been expected (Billig, 2005:192).

To sum up, humour may be understood as both a rhetorical strategy through which to break with social norms, taking pleasure in saying or doing what otherwise is forbidden, and a discursive tool with which to impose the social order. By laughing at the breaking of social norms, we may simultaneously entrench them. Many theorists of humour have pointed out that for humour to work, the discursive act needs an element that is inconsistent with our expectations (e.g. Simpson, 2003). However, Billig complicates this theory by stating that not all incongruities are equally humorous. They depend on power relations in specific contexts, not least the question of who is making fun of whom. In other words, incongruities cannot be analysed separately from hierarchical social relationships (Billig, 2005). This, in turn, raises the issue of entitlement, of who has the legitimacy to make urban vernaculars comic, and who may imitate the Other's voice without sounding disparaging.

At this juncture, it is important to clarify what we mean by the Other. As a large body of scholarship in cultural studies, critical discourse analysis and interactional sociolinguistics has convincingly illustrated (see e.g. Said, 1978; Rampton, 1995; Coupland, 2007), the Other is a 
relational subject position created discursively by speakers/writers. For example, talking about immigrants disparagingly is a way through which the Swedish Self can (re-)position itself as 'superior' (see e.g. Author 3). Yet it is also possible to use the Other's voice (e.g. by putting on a specific accent) for a variety of purposes. According to Bakhtin (1981:362) voicing the Other is 'an artistic image of another's language'. In other words, it is a form of stylization, a performance through which the speaker puts on a recognizable voice. Rampton (2009:149) explains stylizations as interactional occasions when participants produce 'specially marked and often exaggerated representations of languages, dialects and styles that lie outside their own habitual repertoire (at least as this is perceived within the situation at hand)'. This allows speakers to play with 'stereotyped personas and genre' derived 'from well-known identity repertoires' (Coupland, 2007:154). The humour embedded in the use of stylizations takes as given that the voices being imitated are recognizable. With help of stylization of one's own or the Other's voice, we can make fun of, criticize, or embrace a discursive subject position. Finally, by emphasizing the concept of performance in stylizations, Coupland (2007) reminds us of the importance of an audience - present or not in relation to what a speaker says. Humorous performances may break with everyday discursive norms, at the same time as the stylized voices or articulated stereotypes may be legitimized by the ludic situation.

\section{Data}

The material analysed in this article is part of a larger corpus of data collected over the past fifteen years with the aim to understand the social life of Rinkeby Swedish. The data set includes: media outputs (commercials, newspaper articles, radio shows, TV interviews, YouTube videos, and recordings of public panel debates), ethnographic observations and recordings of naturally occurring interaction in schools, as well as interviews with teachers, principals and pupils (see also Author 1, 2007; Author 3, 2010; Author 3 and Author 1, 2012). Four secondary school ethnographies conducted between 2002 and 2016 have been particularly useful for our understanding of the humorous aspects of the use of urban vernaculars. While interacting with students during fieldwork, the first author heard them refer to jokes on TV, YouTube, and the radio. They were commenting on the jokes, laughing at or rejecting them as not funny. Although we do not have space to present the adolescents' talk about the examples we have chosen to discuss in this article, their suggestions to the researcher, concerning which comedians and media platforms to follow, contributed to the selection of data. The examples below were also chosen based on their popularity in the 
Swedish media landscape. Although we only have space to analyse four excerpts, we have watched the comedians' full production of comic programmes, which allowed us to gain a deeper insight into the humour strategies and the personae played out in the skits.

The first extract is from the Little Al-Fadji ('Lilla Al-Fadji') radio show, which was broadcast on Swedish public radio from 2009 to 2017. Little Al-Fadji is probably the best-known comedian using Rinkeby Swedish to a humorous effect in the Swedish media. The second excerpt is taken from Fille's school of slang ('Filles slangskola'), a sketch by the rap artist Felippe Leiva Wenger (who also plays Little Al-Fadji on radio) included in the family television programme So much better ( 'Så mycket bättre'), where famous Swedish musicians meet and play each other's songs. The third example is part of the sketch comedy series on YouTube Language for everyone ('Språk för alla'), which started in 2014 as an Instagram account, and has become a huge success in Sweden, with upwards of 380,000 followers - a huge number by Swedish standards. The last excerpt, from the short film 'Rinkebysvenska' (lit. Rinkeby Swedish but the title of film in its English release was 'Ghetto Swedish'), stands in contrast to the others, as a more highbrow attempt at social critique. The film received considerable media attention and was named best film at the Swedish film festival Stockmotion. As we illustrate in more detail below, while the film Rinkeby Swedish highlights the hidden power relations in the entertaining use of Rinkeby Swedish, the other three texts serve as distinct examples of how speakers of Rinkeby Swedish are produced as jocular figures.

\section{Little Al-Fadji: laughing with and at the stereotype}

The first example of what we may call the comic immigrant Other is Little Al-Fadji. The show was created by the Swedish rap stars Felippe Leiva Wenger and Fredrik Eddari. Leiva Wenger was born in Chile, moved to Sweden as a young child and grew up in Vårberg, a multiethnic neighbourhood in the outskirts of Stockholm. Eddari was born in Sweden from a Swedish mother and a Moroccan father, and grew up in the multiethnic suburb of Rinkeby. In the programme, Leiva Wenger performs the titular Little Al-Fadji, a second-generation young immigrant man. Famous guests are invited onto the show and interviewed in a style that draws more attention to the performance of the interviewer than to the profile of the celebrity. Having listened to all seasons of Little Al Fadji programme, we are confident to conclude that Felippe Leiva Wenger's humour draws on the stereotype of the tough, masculine, sexist, vulgar, and rude young immigrant man, yet performed in a ridiculous and clownish way. It is 
a form of mockery that is inherently ambiguous. While tough masculinity is performed by Little Al-Fadji, it is done in such a way that parodies being masculine and macho. Ambiguity can also be seen in the ways in which the figure of Little Al-Fadji relates to success. He is nearly obsessed with talking about his accomplishments as a celebrity - as well as his sexual conquests and his conspicuous consumption. However, his success stories always contain doubts and embarrassing failures. The journalist Abraham Staifo once described Little AlFadji in a Swedish tabloid (Expressen 12 July 2008) in a way that nicely summarizes the comedy show:

Sexist and extremely vulgar. He sings poorly and has overall very bad habits. He's egocentric and intolerable [...] There are lots of people like him, but this one is an Arab with a mullet and sandals. You have to love him. He resides in one of the Stockholm suburbs and speaks Swedish with a lot of MTV-English, which he masters much less than he wishes to use it. One of his less kind habits is that he constantly calls people idiots. But I melt every time he does so (our translation).

Leiva Wenger employs a stylized Rinkeby Swedish voice to build the persona of Al-Fadji and intersperses his speech with made-up vocabulary and turns of phrase that cannot be found in Rinkeby Swedish. For example, he uses the invented word 'shulululu' (instead of hello), pronounces the Swedish neologism 'fläshigt' (flashy) as 'flääshigt'; says 'feck' instead of fuck; and pronounces Hollywood Radio as 'Hälliewüüd Radio' (which is the name of his show). These words are explained in a glossary on the website of the show. Little Al-Fadji thus carves out for himself a self-made register within Swedish contemporary urban vernacular. Talking in this idiosyncratic and exaggerated way is in fact a crucial part of the humorous keying of the show.

To give an example, in the following excerpt, Little Al-Fadji (LAF) interviews the actor and director Bahar Pars (BP), who is asked to answer some questions that supposedly imply moral dilemmas for her. The excerpt is an example of a typical sequence in the show: Little Al-Fadji employs a highly stylized voice and asks absurd questions. 


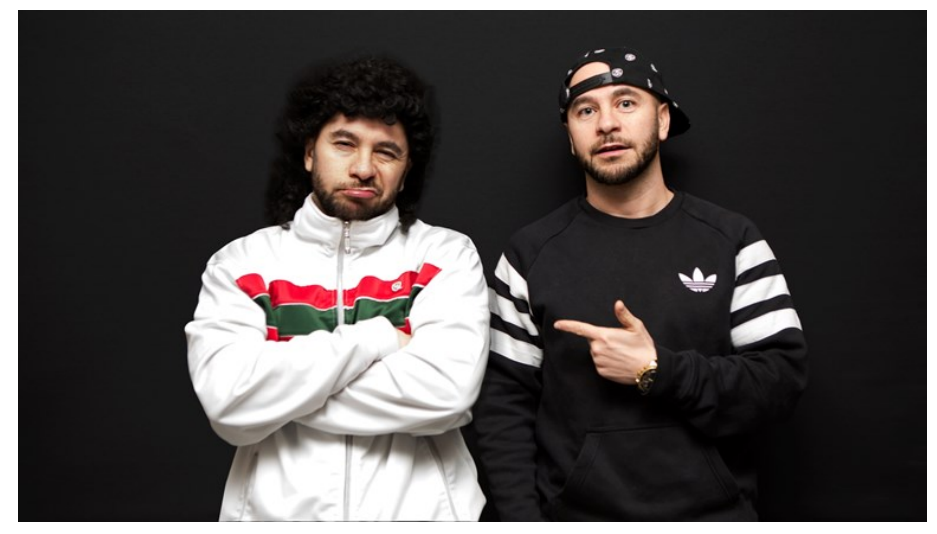

Figure 1: Felippe Leiva Wenger playing Little Al-Fadji (left), and as himself (right)

\section{Excerpt 1 (original)}

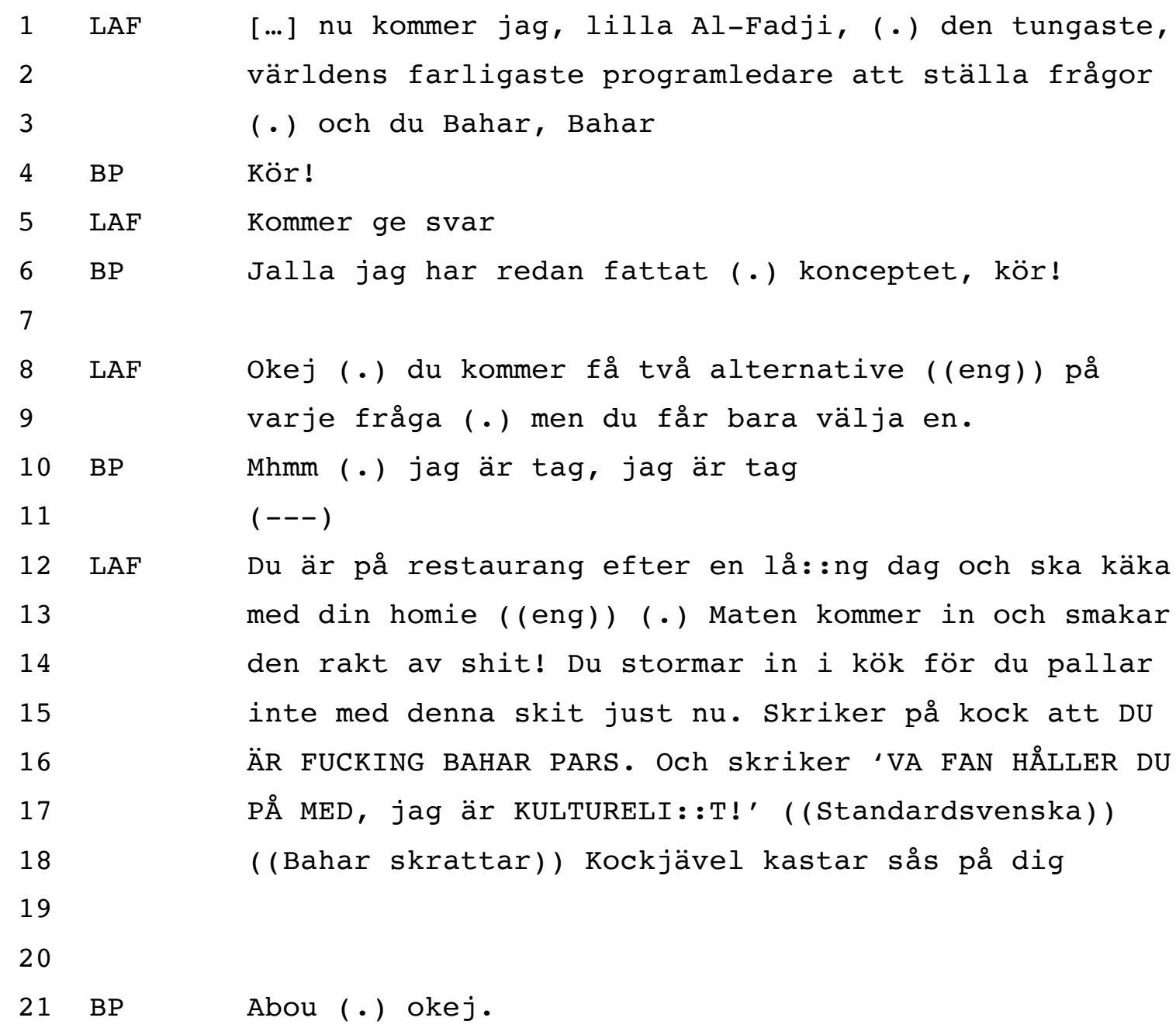

\section{Excerpt 1 (translation)}

1 LAF [...] I, Little Al-Fadji (.) the baddest (('tungaste' is 


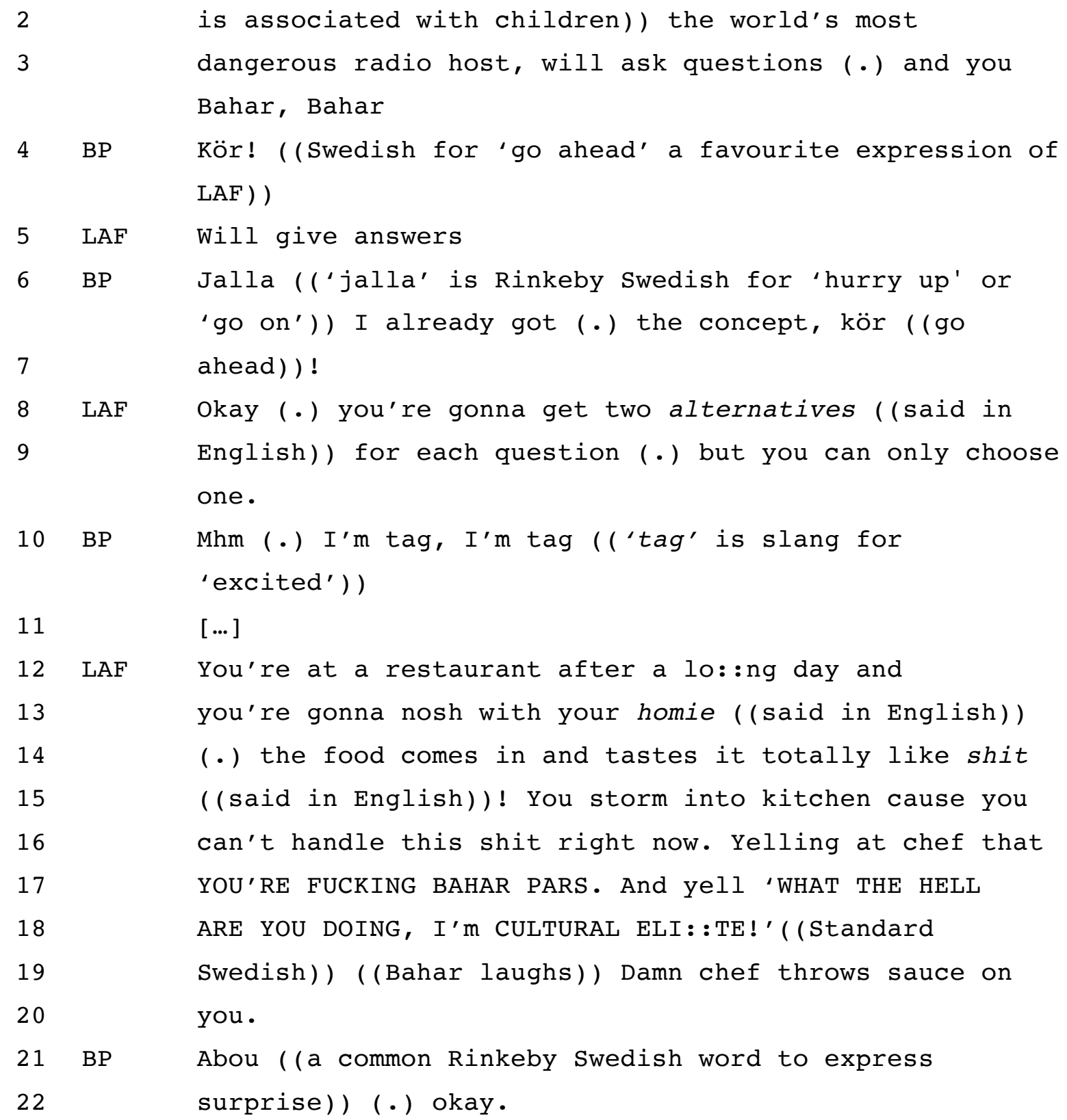

Reading excerpt 1 from a perspective à la Billig, it could be argued that Little Al-Fadji is simultaneously advancing an argument and producing humour: a) on the level of propositional content, he is criticizing the Swedish cultural elite, and b) on the level of form, he makes the stereotypes surrounding this position visible by comically hyper-performing a Rinkeby Swedish speaker. This is achieved through specific linguistic choices: the use of the superlatives 'baddest' and 'the world's most dangerous' to invoke the image of the dangerous, and overly boastful, immigrant Other, is at odds with the character's name - 'little' - and the ostensibly childish mistake of saying 'tungaste' instead of 'tyngsta'. Although 'Lil' is slang 
for rappers in English, when used in Swedish ('lilla'), such connotations of street cred and hip-hop celebrity are lost in translation and turned into a sign of being childish.

Secondly, the unexpected usage of reverse word order in a coordinate clause marks Al-Fadji's speech as non-standard. Needless to say, the distinction between what counts as standard and non-standard is problematic and is the result of specific language ideological processes. However, in the Swedish context, straight word order after a fronted adverbial has become indexically linked with speakers of Rinkeby Swedish (see Røyneland 2018, for similar findings on 'Multiethnolectal Norwegian'). To give an example: igår jag gick instead of the standard word order igår gick jag (lit. yesterday went I). Little Al-Fadji creatively plays with non-standard language usage, this time, through linguistic hypercorrection by employing reversed order in a coordinate clause. He says 'och smakar den rakt av shit!' (line 13) ('and tastes it purely like shit!', non-standard) instead of 'och den smakar rakt av shit!' ('and it tastes purely like shit!', standard).

Thirdly, he incorporates American English-language linguistic resources like 'homie' (line 12) into his speech, yet in a way that is limited to very few words mixed up with various other linguistic styles. Thus, by the very act of using bits of American urban youth style in a hopscotch way, Al Fadji is actually parodying his unsuccessful attempt to sound like an international celebrity. The use of non-standard linguistic resources brings into question the immigrant young man's proficiency in the Swedish language, at the same time as it allows Al Fadji to construct an in-group that excludes the 'cultural elite' (line 18). Here Rinkeby Swedish indexes in-group solidarity, familiarity to neighbourhoods in the multilingual outskirts of Stockholm, and social contestation against a privileged majority (see Rampton, 2015).

By switching to a standard Swedish style when voicing Bahar Pars (line 18), Little Al-Fadji asks Pars if she is still 'one of us' or has become an arrogant and upper-class Swedish elite person who throws sauce at the chef (lines 19-20). However, Bahar Pars resists this ascription by replying with the expression 'abou' (line 21), which is emblematic of Rinkeby Swedish (see also the words 'jalla' (line 6) and 'kör!' (line 4) which often have been singled out as 'typical' Rinkeby Swedish words). Through these linguistic resources, Bahar Pars performs the authentic urban vernacular speaker, and thereby counters Al-Fadji's mocking tone. We can see here how Rinkeby Swedish is a valuable linguistic resource for Pars, who performatively positions herself as belonging to the in-group and aligns herself with Al-Fadji. 
Little Al-Fadji, on the other hand, makes fun of Bahar Pars' privileged position in Swedish high cultural life, by impersonating Bahar Pars shouting to an imaginary restaurant chef in a standard Swedish style that 'she is culture elite' (line 18). However, Pars is not interpellated (Alhusser, 1971) as just any privileged Swede but more specifically as that of the 'diva'. Interestingly, this position is rated as highly desirable in Little Al-Fadji's shows as he often emphasizes his own celebrity status. Thus, when stylizing her Swedish celebrity voice, Little Al-Fadji simultaneously celebrates and mocks Bahar Pars for her success in Swedish cultural life.

At the same time, Little Al Fadji makes fun of himself - the self-absorbed, immigrant man, who presents himself as a worldly, wise observer of the Swedish cultural elite, but who makes obvious language and cultural mistakes that the elite would find amusing. By exaggerating stereotypical characteristics, Al-Fadji appears as foolish, excessive, and credulous. The target of this joke is twofold: it makes fun of both Bahar Pars's integration into the Swedish cultural elite and the immigrant Other, who messes up cultural codes and linguistic norms. Ridiculing the cultural elite mocks the social order. Yet Al-Fadji becomes the target of mockery, the stereotype of the aggressive and dangerous immigrant is contested and softened into a comic figure - one that the audience can laugh at, but also whose company they can enjoy, and whom they can even care for.

Moreover, the performance of the clownish Little Al-Fadji figure suggests the absurdity of the stereotype. To do so, he must both embrace and make fun of the threat embodied by the immigrant Other. Because this stereotype has become so dominant, Al-Fadji's humour can be understood as rebelling against the social order (Billig, 2005). When the 'threatening Other' is made laughable, his threat as an 'immigrant' is neutralized, but, in the comical performance itself this laughable persona still does potentially 'threatening' work, this time towards the unequal social class order, the ugliness of being 'high class', and immigrants' aspirations towards such class mobility. Either way, the jokes are based on a form of recognition - the reproduction of aspects of the stereotypes it seeks to undermine - which also confirms the stereotypes and cements the pre-existing order. Al-Fadji's self-stylizations allow us to laugh simultaneously with and at the Other.

\section{Fille's school of slang: authenticity as entertainment}


In the Swedish reality television program 'So much better', successful music artists meet and play their own versions of each other's well-known songs. During filmed dinner

conversations and various leisure activities, the artists are also encouraged to tell stories about their lives and artistic career. In a 2015 episode, Felippe Leiva Wenger arranges a 'slang school' for the other participants (this might very well be the producer's idea, we don't know, but we analyse this example as scripted by the TV production). In the programme, Leiva Wenger participates as one of the artists, as a part of the hip-hop duo Ison and Fille, who are known for their socially incisive lyrics. In the episode, Leiva Wenger talks about how their lyrics, which are written in what he calls 'Orten Swedish' (i.e. Rinkeby Swedish), expressing what it is like to grow up in their neighbourhoods, poor, and with relatively few possibilities in life.

Leiva Wenger then writes up a list of words, which he says he uses in his hip-hop lyrics. The words constitute the glossary for the language lesson, 'Fille's school of slang' ('Fille' is a shortened nickname for 'Felippe', i.e. Leiva Wenger's hip-hop persona). The lesson is framed as an entertaining way for the other Swedish artists, who obviously have very limited knowledge of this linguistic style, to attempt to pronounce the words on the list. Participants laugh together at their many unsuccessful attempts.
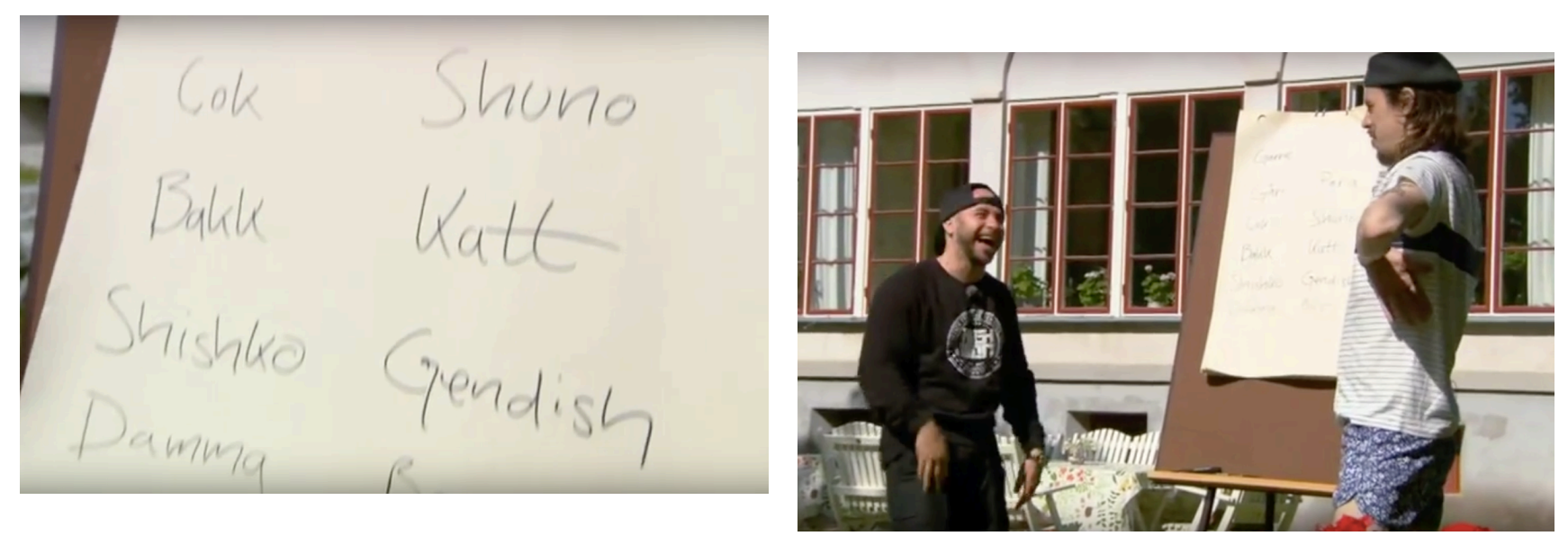

Figure 2: To the left: the list of slang words in 'So much better'. To the right: Felippe Leiva Wenger and Kleerup.

Prominent white Swedish artists such as the elderly actor Sven-Bertil Taube, the pop musician Kleerup, and the singer Lisa Nilsson, generate lots of laughter while trying to construct their own full sentences using the glossary. In excerpt 2, Kleerup struggles to form the plural of the word gäri (meaning girl). In this particular scene, Kleerup is wearing tight shorts with a 
flower print, a striped T-shirt and a beret (see figure 3). His clothes contrast strongly with Fille's, who is wearing black, baggy shorts and a sweatshirt, with a baseball cap turned backwards. Kleerup also displays an exaggerated body language that indexes femininity: he leans on one hip, with his hand on his waist. He finishes his talk by repeating 'nice' (trevligt), a polite, standard Swedish form of agreement. The text below and the bodily gestures are delivered in a very playful manner, and all participants laugh loudly, including Fille.

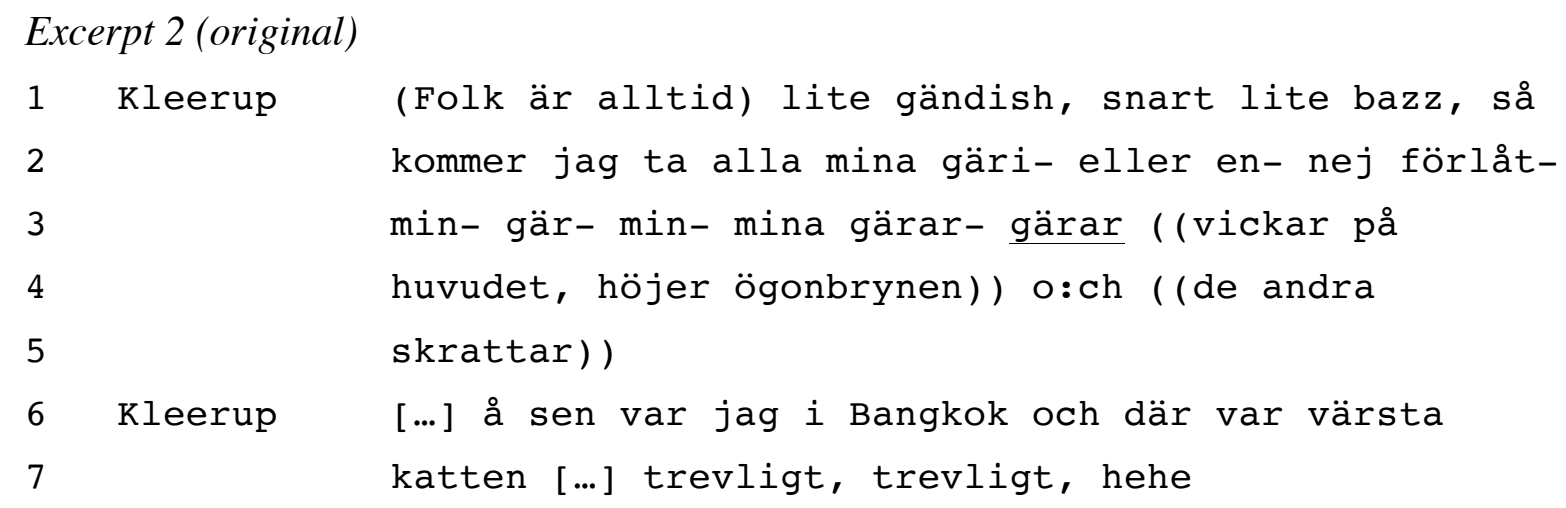

\section{Excerpt 2 (translation)}

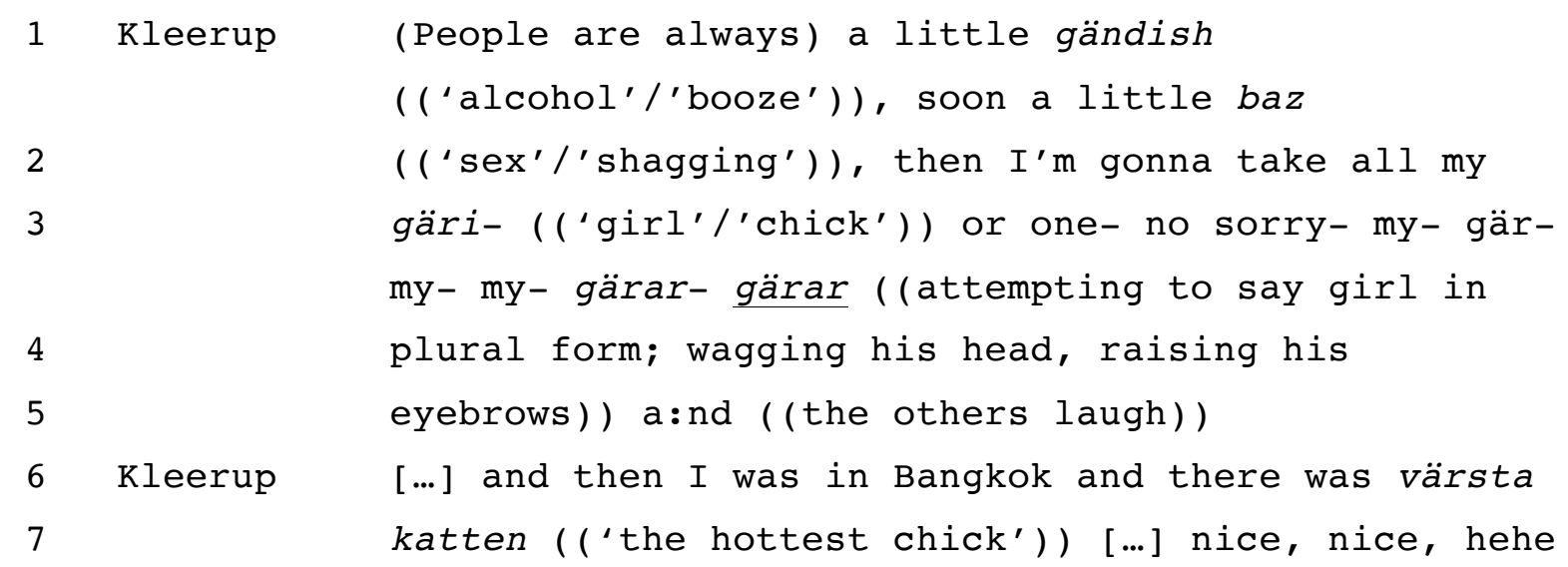

The humour in the scene can largely be located in the incongruities (cf. Billig, 2005) created by the reversal of expected social roles: the Rinkeby Swedish speaker, who is constructed in the media as a figure in need of language education, now occupies the role of a language teacher. The urban vernacular seems to have been given higher status as a language of instruction. At the same time, it is incongruous for Rinkeby Swedish to be placed in such an inauthentic setting, and in the mouths of white Swedish middle-aged artists. Far from the multilingual suburbs where the youth style supposedly originated, the participants are being 
taught slang in a typical Swedish summer 'paradise' - the island of Gotland - a famous holiday resort for the Stockholm elite.

In Excerpt 2, Kleerup comically fails to speak the contemporary urban vernacular. However, the failure in itself is a rhetorical choice, skilfully used in interaction. Kleerup both displays his lack of knowledge of the meaning of the terms, and his lack of the appropriate gender performance: if Rinkeby Swedish is typically associated with an aggressive masculinity, Kleerup is performing a different position, with his flowery shorts and feminine body language. The image of the dangerous, aggressive ethnic Other appears very distant, as all participants take pleasure in jokingly trying out the urban vernacular. Kleerup might be understood as engaging in a type of self-mockery. The parody is not aimed at the perceived authentic Rinkeby Swedish speaker, but at himself, and how silly it sounds when he tries to speak urban vernacular when he clearly is not entitled to it. By exaggerating his mistakes, he distances himself from the category of the 'authentic Rinkeby Swedish speaker', and the laughter of the others serves to confirm this.

At the same time, the laughter (re)produces the distinction between the 'authentic' Rinkeby Swedish speaker, and the 'inauthentic' one. Rinkeby Swedish speakers are constructed anew as having to look and sound a particular way. Even as Kleerup is clearly inviting everybody to laugh at him, their laughter could be understood as an instance of ridicule for disciplinary purposes: As Billig writes: '[...] ridicule is both a means of disciplinary teaching and the lesson of that teaching' (2005:177). The laughter reinscribes the notion of a line between 'us' and 'them' that creates a dichotomy between the masculine and aggressive authentic Rinkeby Swedish speaker on the one hand, and the feminine pretender Kleerup, a speaker of standard Swedish, on the other. While linguistic hierarchies seem to be temporarily reversed in the scene, they are actually covertly reproduced. Without a taken for granted idea of a standard Swedish norm, Fille's school of slang would not be funny at all. 


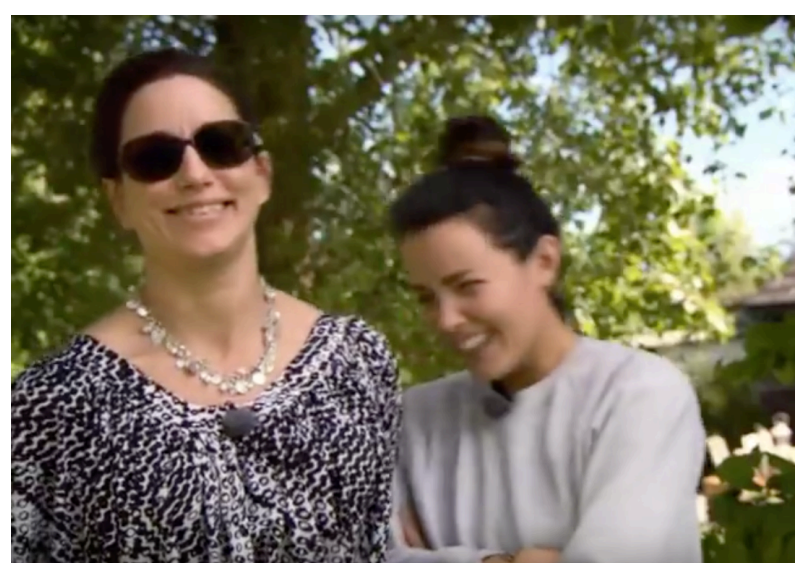

Figure 3: Lisa Nilsson and Miriam Bryant

In the next scene, some of the artists participating in the slang school comment on how much they enjoyed it. Here the pop stars Lisa Nilsson and Miriam Bryant comment on the word baza (to have sex), which was part of Fille's list of 'Orten' Swedish words:

\section{Excerpt 3 (original)}

$\begin{array}{lll}1 & \text { Lisa } & \text { Det har inte blivit nåt baz överhuvudtaget på den här } \\ 2 & & \text { resan! } \\ 3 & \text { Miriam } & \text { Nä det är väldigt lite, dåligt med baz här på } \\ 4 & & \text { Gotland (---) man får baza ikapp sen när man kommer } \\ 5 & & \text { hem ( (skratt)) } \\ 6 & \text { Lisa } & \text { Man får baza på när det bjuds! ((båda skrattar)) }\end{array}$

\section{Excerpt 3 (translation)}

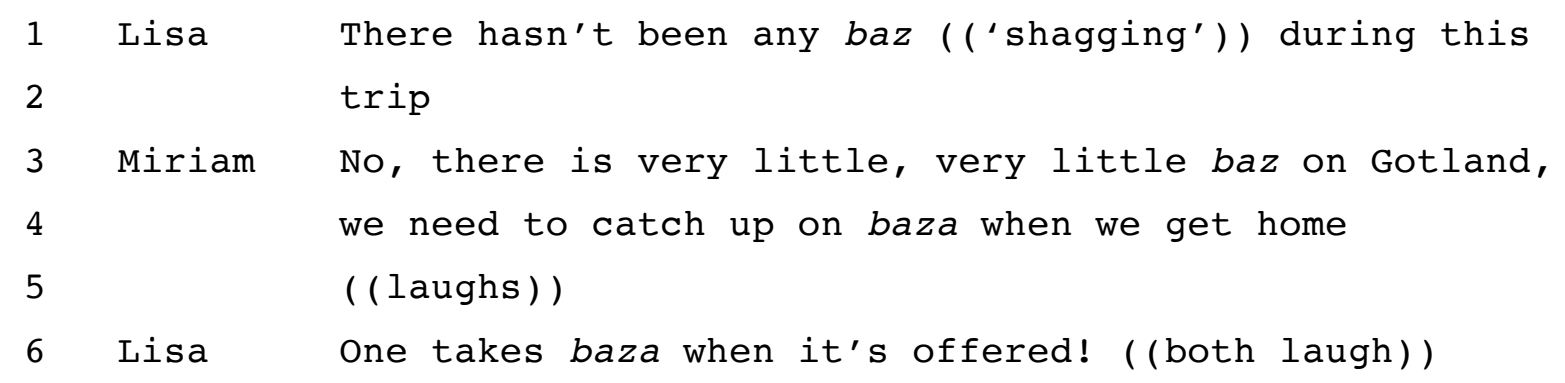

On line 6, Nilsson humorously replaces the word 'passa' with ' $b a z a$ ', and thereby turns the Swedish saying 'Man får passa på när det bjuds' (one should be alert to opportunities and take them when offered) into 'Man får baza när det bjuds' (one should fuck when the opportunity is offered). Aside from the creative twist on words, the comic effect arises from an incongruity: white, middle class people are not expected to discuss sex in these terms in a 
prime time and public setting. This comic situation is also quite ambiguous. On the one hand, Lisa Nilsson's play on 'passa'/'baza' may be understood as radical - as a feminist speech act that asserts the right for women to talk about their own desires and ask for more sex on a public family show. In this way, she is opposing a masculinist social order in which women are not supposed to speak overtly about sex. On the other hand, the humour in the scene comes at a price.

In Fille's school of slang, we are primarily laughing at the successful Swedish artists, who make fools of themselves while trying to speak Rinkeby Swedish. Their poorly performed slang indicates to the audience that they are not claiming to be entitled to use the words. This claim relies on the implicit construction of the authentic voice of the urban slang speaker - the voice that they fail to imitate. According to the Freudian 'relief' theory of laughter (Freud, 1905/1991), humour gives expression to what should normally be repressed in social life. When Lisa Nilsson asks for 'more $b a z$ ' (sex), she is talking about sex on TV by ventriloquizing (Tannen, 2001) the immigrant Other. In doing so - although the words are being guided by the TV script - she discursively constructs for herself the subject position of a sexually active woman who wants to have fun. However, this is achieved by relying on the stereotypical associations between the Rinkeby Swedish speaker and sex talk. In this way, the joyful laughter of the participants could also be understood as disciplinary laughter (Billig, 2005). The humour is founded on, and reproduces, the stereotypical image of the sexually voracious male Rinkeby Swedish speaker.

That being said, the urban vernacular and its speaker are simultaneously the objects of celebration. Filles's 'school of slang' is greatly enjoyed by the participants. The scene sets a pleasant and entertaining mood for the rest of the TV program. Participants are delighted; the laughter seems never to end. 'So much better' could thus be understood as an example of so called 'happy talk' (Bell and Hartman, 2007) and 'happy hybridity' (Otsuji and Pennycook, 2010), a manifestation of a diversity discourse which fails to account for power relations, and thereby shifts focus away from an explicit disavowal of linguistic hierarchies, toward a rhetoric that aspires to acknowledge and celebrate linguistic diversity as well as the immigrant Other.

\section{Language for everyone: diversifying the ridicule}

Following the hyperbolic construction of the immigrant Other as a clown figure by Leiva 
Wenger, the 'immigrant Other' has also been transformed into more a more complex and contradictory figure. A set of such examples has been created by the comedians Toni Prince Tvrtkovic and Amir Halim. Tvrtkovic and Halim were born in the late 1990s in Stockholm. They present themselves in social media and interviews as Swedish actors. At times, they do refer to a Swedish, Serbian and Arabic family background, mainly as a response to journalists' questions about their ethnic origins. However, they are not claiming any 'own authentic' ethnicity or any specific place of belonging in the city when presenting themselves on their social media platforms. They are keen to describe themselves as Swedish entertainers or entrepreneurs. Since 2014 the duo uses Instagram, YouTube, and Facebook to disseminate the popular short video clips that constitute the 'Language for everyone' series. The clip analysed below was downloaded from their YouTube channel.

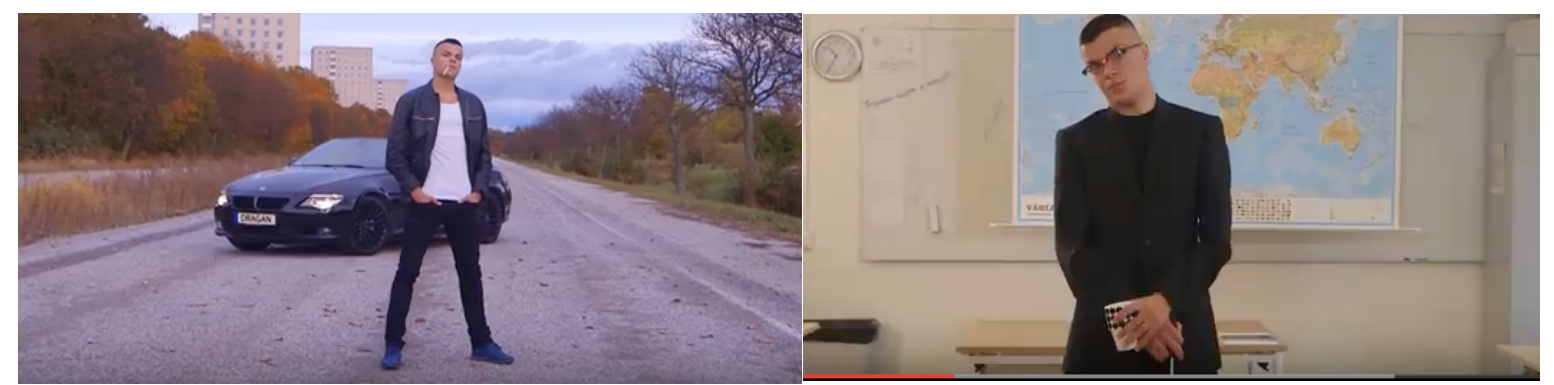

\section{Figure 4, Characters from 'Language for all'}

Tvrtkovic and Halim draw on numerous stylized voices in their skits, which direct their biting humour to a number of different cultural stereotypes. They imitate Swedish mothers preparing their sons for a summer camp by packing their suitcases full of highbrow literature; Yugoslavian parents sharing their concerns about their son catching a cold while sitting in a draft, not wearing warm socks, or leaving home with wet hair; and a Swedish teacher who is trying to teach Rinkeby Swedish in an inappropriately academic register: 'Next lesson, we'll discuss shurda ('bloke'), bram ('bro') and ba'ad ('there's more') (.) Study abou ('wow') and len ('bruv')! These are vital conjunctions!' In this last example, words emblematic of Rinkeby Swedish are deployed that steer clear of the lexicon stereotypically associated with sexist epithets for women, and sexual terminology. Through their Instagram skits, Tvrtkovic and Halim represent a 'new generation' of actors using Rinkeby Swedish. However, they do so by displaying a much wider multilingual competence (Kramsch, 2009). This bears some resemblance to Røyneland's finding that young people with 'mixed backgrounds' in Norway, through their employment of multiethnolectal features and multilingual practices, 'assert the validity of identities that are multiple and mixed' rather than unitary and pure (2018:167). The 
comedians are both proficient in Rinkeby Swedish and standard Swedish. Such linguistic skills open up the possibility of moving between various identity positions and at the same time erase fixed boundaries between Swedishness and non-Swedishness. Their way of switching between different linguistic styles is in itself an important performance of a young linguistically and culturally competent persona who cannot be easily boxed into 'the ethnic Other'.

They make fun of - and reproduce - stereotypic images based on age, class, race and ethnicity. Having said that, the unified figure of the sexist Rinkeby Swedish speaker, whom Leiva Wenger made comically absurd in his character Little Al-Fadji, is absent in 'Language for everyone', and is replaced by a plethora of different personas comically engaged in various mundane social interactions. In Excerpt 4, an adult teacher is speaking to four young characters: an upper-class Swedish brat ('Brat'), a feminine gay man who is also Swedish ('Måns'), a Latino man ('Latino'), and an ostensibly Turkish immigrant ('Orhan’) who speaks Rinkeby Swedish. These characters appear in a number of different situations across a number of sketches. What is being parodied in Excerpt 6 is their plans for a future after high school.

\section{Excerpt 4 (original)}

(Orhan is played by Halim, all other characters played by Tvrtkovic).

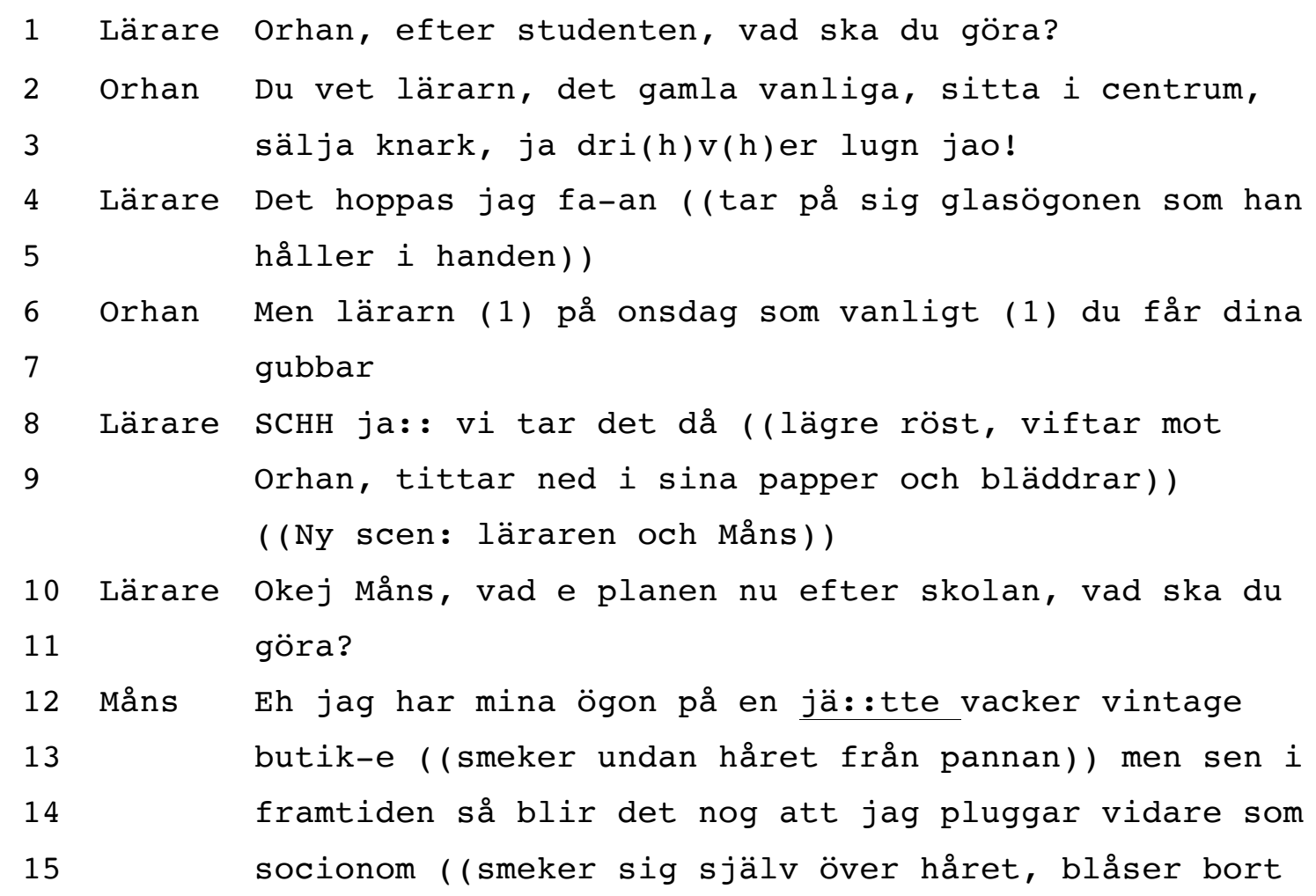


luggen från ansiktet)). Det tror jag jag kommer bidra mycket med.

( (Ny scen: Latinokillen))

25 Brat

Latino Ey, ja vet inte ((stoppar in en nöt $i$ munnen och tuggar högt)). De finns salsaklubben ((läspar)) inne i city, Fernando Rodrigo Cuadrado. Ja ska jobba där men ja vet inte. (xx), han ger mig jobben, annars ja klarar mig, de e ett jättebra land $i$ Sverige de finns möjligheterna. ((Slänger in en till nöt i munnen och tuggar högt))

((Ny scen: Läraren och Brat))

Brat Jag ve:t inte (.) ja tar väl över efter farsan. Han vill åka ut till landet så jag får väl bo kvar i trehundra kvadrataren, ja har ju fem syskon som är typ fyrtio, så ja e yngst så jag får båten också tror ja, vi har ju två våningar på strandvägen så du är välkommen att ta den ena heh:: ::: skoja hh. ((Vänder bort blicken med ett litet leende))

Lärare Va kul att du har en plan! ((tittar upp från sina papper och ler))

Brat No pain ( (för en knuten näve mot sin kind)), no gain ((Öppnar den knutna näven och smeker sig själv över kinden)) hehe.

\section{Excerpt 4 (translation)}

1 Teacher orhan, what are you going to do after graduation?

2 Orhan You know teach, the usual, hang around in the centre, selling drugs - just joking, take it easy dude! (('jao' is a typical Rinkeby Swedish word))

Teacher I frea: :king hope so! ((puts his glasses on))

6 Orhan But hey, teach (1) on Wednesday as usual (1) you get your dope ( (new scene: teacher and Måns))

10 Teacher Okej Måns, what are your plans for after school, what are you going to do? 
Eh I have my eyes on a re: ally beautiful vintage sto:re ((sweeps away his bangs)), but, then, later on, I'll probably end up studying to become a social worker ((caresses his own hair, blows away the bangs from his face)). That is where I think I can make an important contribution.

( (New scene: Latino guy))

18 Latino

Ey, I dunno ((throws a nut into his mouth and chews loudly)) there is the salsa club ((lisping))

34 Brat No pain ((points his fist at his cheek)), no gain

It is worth noting that Toni Prince Tvrtkovic and Amir Halim make fun of the teacher and parental figures as frequently as they do of young people and their linguistic styles. They mock the young Rinkeby Swedish speaking man, Orhan, who has no ambition aside from selling drugs (lines 2-7), while at the same time sending up his teacher who, behind his façade of correctness, hypocritically buys drugs from Orhan (lines 6-9). The Latino guy does not remain unscathed either in his reliance on others to help him - his friends and the Swedish welfare state (lines 19-26). He says that his personal contact will 'fix a job for me, otherwise 
I'll be fine, it is a very good country in Sweden, there are always other possibilities'. This is a joke that draws on the racist stereotype of immigrants living on social welfare. The spoiled rich brat also becomes the target of humour: through his insincere offer of his second flat, he places himself in a superior hierarchical position to his teacher, who appears eager to take him up on the offer (lines 31-34). Thus, Halim and Tvrtkovic draw on categories and linguistic styles related to age, generation, social class, sexuality, profession, race, ethnicity, and nationality.

All of these categories become objects of ridicule. In drawing on so many different characters, Halim and Tvrtkovic also diversify the picture of life in contemporary urban Sweden (see also Røyneland, 2018). In excerpt 4, one and the same actor, Tvrtkovic, switches between voicing the adults, the youths, the standard Swedish speakers and a lisping Latino (line 21). In Language for everyone, the comedians themselves emerge as well-informed multilingual young subjects living in a diverse society, able to perform linguistic proficiency in a number of different styles, and to employ these linguistic skills to make fun of well-known identities and linguistic registers. A recurring point in their skits is that the personas they mock - the police, the teacher, the tough Balkan father, or the soft Swedish mother - have a limited linguistic repertoire compared to the multilingual youth. Who is being sent up by whom, and who might thus be offended (Pickering and Lockyer, 2005), may not be immediately clear.

While the jokes build on existing stereotypes, thus reproducing them, the meta-message in the humour is that Rinkeby Swedish speakers (such as the two comedians) are linguistically talented, and have the ability to make reflections on cultural and societal norms as well as gendered, ethnic, racial, and generational positions and relations. The arguments advanced in the skits are: (1) that linguistically and socially limited personae are comical, and (2) that being linguistically and socially flexible is highly valuable. Tvrtkovic and Halim are making fun of categories (i.e. the brat, the latino, the teacher), all of which they themselves do not claim to belong. However, they portray the youths from the multi-ethnic suburbs in the plural: he (for it is always a man that is portrayed) is no longer a fixed persona but comes in various forms and sub-categories - like Orhan and the Latino guy in Excerpt 4. Their comedy also works to break down some of the borders between well-to-do central Stockholm and the city's more peripheral neighbourhoods, between ethnic Swedishness and multi-ethnic Sweden. Orhan, the 'Brat', Måns and the 'Latino' are represented as belonging to the same milieu, even sharing the same teacher. 
In contrast to this characterological diversity, we will now return to Bahar Pars, whom we met earlier in the interview with Little Al-Fadji (Excerpt 1). This time, we analyse an extract from the short film 'Rinkeby Swedish', which is an example of social critique of the Swedish colour blind discursive regime in which overt racist and utterances are frowned upon. However, as it emerges in Par's film, the humorousness of Rinkeby Swedish, as well as the Swedish antiracist discourse, is a highly contestable issue.

\section{'Rinkeby Swedish': when the killjoy says we should not laugh}

In the film 'Rinkeby Swedish', the Swedish, Iranian-born, director Bahar Pars suggests that there is nothing to laugh about when it comes to contemporary urban vernaculars. While humour was used in all of the examples above, the following example - from Pars's awardwinning short film - makes the point that it is our expectation of laughter, of being entertained by Rinkeby Swedish, that is deeply problematic.

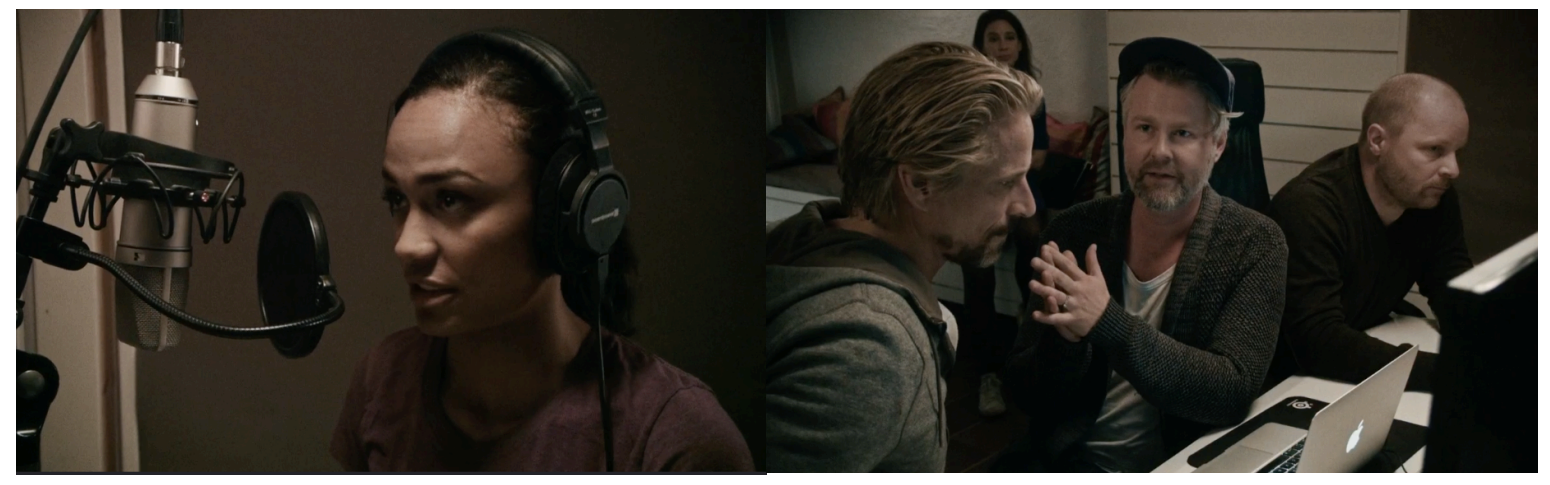

Figure 5: To the left, the character Aisatou; to the right, two producers from the film 'Rinkeby Swedish'.

In the 2015 film 'Rinkebysvenska', the actor of colour Aisatou, played by Nanna Blondell, is asked to read a voiceover for an advertising agency. However, to the great disappointment of the two producers at the agency, Aisatou does not employ the linguistic style they expected. Instead, Aisatou starts her reading in standard Swedish:

\section{Excerpt 5 (original)}

1 Aisatou Sakta du går genom stan (.) du känner pulsen slå, och 


\section{Excerpt 5 (translation)}

1 Aisatou Slowly, you walk through town (.) You feel the beat of 2 your pulse, and suddenly, out of nowhere, you understand that you have changed

'Thank you' the two producers interrupt in the middle of Aisaotu's reading - and they start giving her directions:

\section{Excerpt 6 (original)}

$\begin{array}{lll}8 & \text { Prod 2 } & \text { Eh f-får jag ba säga en sak, jag tror inte att du } \\ 9 & \text { behöver vara så lugn e:h j-ja tror att texten } \\ 10 & \text { kommer fram mycket bättre om du- om du ger de lite } \\ 11 & & \text { kraft- lite energi så där FATTAR RU! Så där, eller } \\ 12 & & \text { va säger du, lite mer girlpower FATTA RU, förstår } \\ 13 & & \text { du (ler)? } \\ 14 & \text { Prod 1 } & \text { Tack tack Aisa, får jag kalla dig Aisa? } \\ 15 & \text { Aisatou } & \text { Heh ah visst } \\ 16 & \text { Prod 1 } & \text { Vi kan också säga så här Aisa, det är Måns som } \\ 17 & & \text { pratar nu, jag tror vi skiter i att vara så } \\ 18 & & \text { pedagogiska, ja tror vi ska tänka oss istället va- } \\ 19 & & \text { va- va skulle Aisa göra, eller va skulle du säga i } \\ 20 & & \text { den här situationen }\end{array}$

\section{Excerpt 6 (translation)}

8 Prod 2 Eh c- can I just say one thing, I don't think you have to be so calm, e:h I- I think the text will come out much better if you- if you give it some power - a little energy like 'DO YOU GET IT'! ((imitating the style of an aggressive interrogative similar to 'capeesh?' in American Italian English)). Like that, or what do you say, some more girl power 'DO YOU GET IT', do you understand? ((smiles)) 
After telling Aisatou to draw on her own personal experience and voice, 'what would Aisa do, or what would you say' (lines 18-20), the producers encourage her to 'just let it flow'. They want her to sound 'less calm' (line 9) and use more 'energy' (line 11). Later in the film, they go on telling her to be 'more gangster' and show 'more girl power'. One of the producers finally says: 'I want you to try something, I want you to try ... try ... Rinkeby Swedish'. Thus, the film rhetorically displays the white producers' desire for a performance of the Other's voice. When Aisatou still fails to deliver what the producers want, they sigh, pick up a pre-prepared list, and say: 'we, we have to follow the list anyway ... let's see [starts reading from a list of words] aina, axa, aide [words that are emblematic of Rinkeby Swedish]'. Eventually, the two producers get Aisatou to read the voiceover using the Rinkeby Swedish so-called 'staccato' style. And they give each other a high five when they hear her using ' jao' and 'abou' - two other emblems of the register.

What is remarkable is that several of the examples presented above - Little Al-Fadji's website, Fille's school of slang, and the Rinkeby Swedish film - make use of glossaries. In the first two examples the lists of Rinkeby Swedish words have an entertaining effect. Little Al-Fadji's idiolect is comical, and the glossary of authentic words in Fille's slang school is used to entertain the audience. In Bahar Pars' film, by contrast, a critical gaze is directed towards the very existence of the glossary. The scene in the studio becomes comical in a critical sense - the producers get frustrated when having to openly direct Aisatou to speak authentic Rinkeby Swedish. Once again, humorous performances are multi-layered: at the level of form, the film makes fun of the word list, while, at the propositional level, the film also advances the argument that the enjoyment of listening to the Others voice is part of a colonial and gendered discourse. Two white Swedish men tell non-white Aisatou to be 'less calm', 'more gangster' and show more 'girl power'. These are calls that are deeply rooted in stereotypical ideas about who a female Rinkeby Swedish speaker should be and what she 
should say. What emerges most powerfully here is that the only non-white figure in the drama is overtly pointed out as the authentic Other, who is expected to speak 'Rinkeby Swedish' but refuses to do so. However, we are not supposed to laugh at Aisatou, but at the film producers and their stilted views.

When Aisatou does not speak Rinkeby Swedish, she becomes, in Ahmed's terms, a 'killjoy'. The feminist killjoy 'bring[s] others down not only by talking about unhappy topics such as sexism but by exposing how happiness is sustained by erasing the very signs of not getting along.' (Ahmed, 2010a:66). By the same token, in our example, the cheerful mood in the studio, and the joy of recording 'authentic' Rinkeby Swedish are threatened by Aisaotu's unwillingness to perform. Ahmed asks (2010a:65-66) 'Does the feminist kill other people's joy by pointing out moments of sexism? Or does she expose the bad feelings that get hidden, displaced, or negated under public signs of joy?' Aisatou's performance and her linguistic styles embody these questions, bringing to the surface a story of Othering and discrimination that we are trying to suppress (see Ahmed, 2010b).

With her film, Bahar Pars urges viewers not to forget the stories of racism that surround popular ideas of Rinkeby Swedish. Aisatou's distressed face, and her refusal to laugh when it is clear the producers expect to sustain a pleasant atmosphere, reminds us of the Othering and discrimination embedded in the white men's desire for Rinkeby Swedish. Pars's critique is clear: the biting mockery is aimed at the two white producers. The men appear laughable both in their ignorance, and in their usage of Rinkeby Swedish despite not being 'legitimate' speakers. This instance of humour bears resemblance to the carnivalesque (Bakhtin, 1984; Bergson, 1999; Billig, 2005), in which those in powerful positions in society are being put on display, scrutinized, and mocked publicly. Pars' film thus powerfully demonstrates the argumentative nature of humorous performances. There is a contestation of social order in the mocking of white, Swedish men.

However, while this type of humour clearly has rebellious critical intentions, it also builds on and reinscribes a pre-existing social order, which, as Billig (2005) reminds us, is present even in the most well intended rebellious humour. In order to deliver a clear and mocking message of the (otherwise often hidden) oppression of non-white youth in Sweden, the social order is being clarified (cf. Billig, 2005). On the one hand, the film raises important questions about what Rinkeby Swedish is and who counts as an 'authentic' speaker. This is a subject position that Aisatou actively refuses to inhabit. The film also presents the figure of the 'know-it-all' 
white man, who thinks to be well-informed of which linguistic features are 'authentically' Rinkeby Swedish and obstinately pushes Aisatou to use them in order to show her 'authentic' identity. Precisely because of his obtuse pig-headedness, the white man becomes laughable. In doing so, the film delivers a formidable critique of power relations, but it also runs the risk of reproducing stereotypic dichotomies.

\section{Conclusion}

Urban vernaculars might indeed have become signs of ethnic otherness; they have been associated with various social problems and with a threatening, sexist and homophobic masculinity (see Author 3 and Author 1, 2011, 2012). But, as the examples in this article illusatrate, the figure of personhood of the Rinkeby Swedish speaker is not monolithic; nor does it remain uncontested but is constantly being (re)negotiated in the media. By drawing attention to those humorous performances that rhetorically make fun of entrenched stereotypes, the article explored the subversive, as well as disciplinary, potentials of this kind of humour.

Granted, we do not wish to convey that we are witnessing a shift through which Rinkeby Swedish, as an icon of Otherness, is replaced by another figure. On the contrary, the threatening Other and the comical Other are synchronously present; they simultaneously compete and depend on each other, and the ambiguity of humour allows these figures to coexist. Without the threatening Other, the jokes in the examples simply would not work. One question remains to be answered though: Does this mean that rebellious humour, at all times, reproduce the very discourse it criticizes? Put differently, can humorous acts ever be truly subversive?

If we acknowledge the underlying critique of linguistic norms and racist structures in the first excerpt, we can see how the text works as rebellious humour: Little Al-Fadji challenges the image of the threatening Rinkeby Swedish speaker by reconstructing him as a comical and childish figure. His jokes draw on the unfunny side of a sexist and threatening masculinity. This is a mockery of both a) a masculinity that Little Al-Fadji hyper-performs and b) stereotypes surrounding the Rinkeby Swedish speaker within a colour blind, antiracist, Swedish public discourse. At the same time, his humorous stylization of the Rinkeby Swedish speaker creates an in-group where the 'Swede' is being excluded (see Rampton, 2015). 
In a similar vein, Felippe Leiva Wenger, when invited to teach slang in a scene of 'So much better', might challenge ideas of the Rinkeby Swedish speaker as the threatening Other. Yet, it still became obvious in the humorous setting that Fille is interpellated (Althusser, 2001) as the authentic Rinkeby Swedish speaking Other, something which is confirmed by the joint laughter when the other participants attempted to speak Rinkeby Swedish. The old figure is thus being reproduced yet in a celebratory form. The reversal of linguistic hierarchies in Fille's school of slang is a chimera - the entertaining atmosphere in the TV episode makes sense only in relation to a taken for granted ideology of a standard Swedish. This may contribute to the 'celebration of happy hybridity' as an unreflected and problematic 'category of cultural diversity that somehow provides solutions to sociocultural relations and conflicts' (Otsuji and Pennycook, 2010:244). Nonetheless, the very same laughter reproduces the Rinkeby Swedish speaker as the comic ethnic Other.

So far, our analysis shows that rebellious humour can indeed work subversively, yet it is also simultaneously disciplinary in nature. The Rinkeby Swedish speaker in the less openly critical 'Language for everyone' is also mocked - but to the same extent as any other characters. While drawing on many stereotypes in their jokes, Prince Tvortkovitc and Halim go in and out of a wider set of identity positions, and thereby they manage to blur some of the fixed boarders of belonging and linguistic practices. The skits in Language for everyone show a greater variation within what could otherwise have been clustered into a single 'Rinkeby Swedish speaker' category.

As Billig (2005) reminds us, not all incongruities are equally humorous and they cannot be analysed separately from hierarchical social relationships. We conclude that the humour in 'So much better' lacks critical perspectives and subversive potentials. Bahar Pars' film 'Rinkeby Swedish', on the other hand, makes oppression highly visible. However, not so much through laughter as through unlaughter. As Ahmed (2010a) points out in her discussion of the feminist killjoy, to refuse to take part in joyful situations can be understood as a rebellious act. Humour though is still used in Pars's film. Here, the laughs are aimed at the foolish white men. The film can thus be understood as presenting traditional carnivalesque humour in which those in powerful positions are the targets of ridicule. The political message of the film bears a strong resemblance to Hill's (2008) argument that the humour embedded in 'Mock Spanish' is always at the expense of Spanish speakers, and therefore part of a racist discourse. However, we argue that this very humour, with all its rebellious aspects, might also work to reinforce the existing order (see Billig, 2005). The film mocks the Swedish privileged 
man and emphasizes that he is not entitled to use Rinkeby Swedish - which in turn reproduces who the authentic speaker really is.

To conclude, these mediatized stylizations of Rinkeby Swedish allow their performers to discuss racial and social stratification in ways that the predominant colour-blind and antiracist discourse does not allow. While Aisatou in Bahar Pars' film suggests that the stereotype of the Rinkeby Swedish speaker ought to be abandoned altogether, both 'Language for everyone' and 'Little Al Fadji' contend that we should celebrate and upgrade it. Little Al Fadji's jokes draw on the stereotypes surrounding the immigrant Other as a young man. 'Language for everyone', on the other hand, unpacks it, and points towards a multiplicity of voices and personas in the multilingual suburb. In these jokes we do find a subversive potential: The 'exemplary speaker' of contemporary urban vernacular (Androutsopoulos, 2016) can be laughed at and with, and laughter can also be resisted, but this characterological persona cannot easily be fixed into a unified homogenous figure.

\section{REFERENCES}

Author 1, 2007

Author 1, 2018

Author 1 and Author 3, 2009

Author 3 and Author 1, 2011

Author 3 and Author 1, 2012

Author 3, 2010

Agha, A., 2007. Language and Social Relations. Cambridge University Press, Cambridge, England.

Agha, A., 2011. The social life of cultural value. Language and Communication 31, 171-180.

Ahmed, S., 2010 a. The Promise of Happiness. Duke University Press, Durham.

Ahmed, S., 2010 b. Feminist killjoys (and other willful subjects). Scholar and Feminist Online.

Althusser, L, 2001. Lenin and Philosophy and Other Essays. Monthly Review Press, New York.

Androutsopoulos, J, 2016. Performing the exemplary speaker: Multimodal enregisterment in German ethnic comedy. Keynote address at CADAAD 7, University of Catania, Italy, 57 September 2016.

Bakhtin, M., 1981. The Dialogic Imagination. University of Texas Press, Austin.

Bakhtin, M., 1984. Rabelais and his World. University of Texas Press, Austin.

Bell, J. M., Hartman, D., 2007. Diversity in everyday discourse: The cultural ambiguities and consequences of 'happy talk'. American Sociological Review 72, 895-914.

Berger, P.L., 2014 [2 ${ }^{\text {nd }}$ ed]. Redeeming Laughter: The Comic Dimension of Human Experience. Walter de Gruyter, New York.

Bergson, H., 1999 [1911]. Laughter: An Essay on the Meaning of the Comic. Green Integer, København. 
Billig, M., 2005. Laughter and Ridicule: Towards a Social Critique of Humour. Sage, London.

Cheshire, J., Kerswill, P., Fox, S. \& Torgersen, E., 2011. Contact, the feature pool and the speech community: The emergence of Multicultural London English. Journal of Sociolinguistics 15 (2), 151-196.

Chun, E W., 2013.'Ironic blackness as masculine cool: Asian American language and authenticity on YouTube', Applied Linguistics 34, 592-612.

Coupland, N., 2007. Style: Language Variation and Identity, Cambridge University Press, Cambridge.

Cornips, L., Jaspers, J., Rooij, V. de, 2015. The politics of labelling youth vernaculars in the Netherlands and Belgium. In Nortier J,, Svendsen, B. A., (Eds.), Language, Youth and Identity in the 21st Century: Linguistic Practices Across Urban Spaces. Cambridge University Press, Cambridge, pp 45-68.

De Fina, A., Georgakopoulou, A., 2012. Analyzing Narrative. Discourse and Sociolinguistic Perspectives. Cambridge University Press, Cambridge.

Freud, S., 1991 [1905]. Jokes and Their Relation to the Unconscious. Penguin Books, Harmondsworth.

Goffman, E., 1967. Interaction Ritual. Pantheon Books, New York.

Hay, J., 2000. Functions of Humour in the Conversations of Men and Women. Journal of Pragmatics 32, 709-42.

Hewitt, R., 1982. White adolescent Creole users and the politics of friendship. Journal of Multilingual and Multicultural Development 3, 217-232.

Hewitt, R., 1986. White Talk, Black Talk: Inter-racial Friendship and Communication amongst Adolescents. Cambridge University Press, New York.

Hill J., 1998. Language, race and white public spaces. American Anthropologist 100 (3), 680689.

Hill J., 2008. The Everyday Language of White Racism. Wiley-Blackwell, Chichester.

Hübinette, T., Lundström, C., 2011. Sweden after the recent election: The doublebinding power of Swedish whiteness through the mourning of the loss of 'old Sweden' and the passing of 'good Sweden'. Nordic Journal of Feminist and Gender Research 19 (1), 4252.

Irvine, J. T., Gal, S., 2000. Language ideology and linguistic differentiation. In Kroskrity, P. V., (Ed.), Regimes of Language: Ideologies, Polities and Identities, School of American Research Press, Santa Fe.

Jaspers, J., 2005. Linguistic sabotage in a context of monolingualism and standardization. Language \& Communication 25, 279-297.

Jaspers, J., 2011. Talking like a 'zerolingual': Ambiguous linguistic caricatures at an urban secondary school. Journal of Pragmatics 43, 1264-1278.

Kern, F., Selting, M., (Eds.) 2011. Ethnic Styles of Speaking in European Metropolitan Areas. John Benjamins Publishing, Amsterdam.

Kotsinas, U-B., 1988. Immigrant children's Swedish - a new variety? Journal of Multilingual and Multicultural Development 9, 129-140.

Madsen, L. M., Karrebæk, M S., Møller, J. S., (Eds.), 2015. Everyday Languaging: Collaborative Research on the Language Use of Children and Youth. Mouton de Gruyter, Berlin.

Madsen, L. M., Svendsen, B. A., 2015. Stylized voices of ethnicity and social division. In Nortier, J, Svendsen, B. A. (Eds.) Language, Youth and Identity in the 21st Century: Linguistic Practices across Urban Spaces. Cambridge University Press, Cambridge, pp. 207-230.

Nortier, J., Svendsen, B. A., (Eds.) 2015. Language, Youth and Identity in the 21st Century: 
Linguistic Practices across Urban Spaces. Cambridge University Press, Cambridge. Otsuji, E., Pennycook, A., 2010. Metrolingualism: Fixity, fluidity and language in flux. International Journal of Multilingualism 7, 240-254.

Pickering, M., Lockyer, S., 2005. Introduction: The ethics and aesthetics of humour and comedy. In Lockyer, S., Pickering, M. (Eds.) Beyond a Joke: The Limits of Humour. Palgrave Macmillan, Basingstoke.

Quist, P., Svendsen, A. B., (Eds.), 2010. Multilingual Urban Scandinavia. New Linguistic Practices. Multilingual Matters, Bristol.

Rampton, B., 1995. Crossing. Language and Ethnicity Among Adolecents. Longman, London.

Rampton, B., 2009. Language in Late Modernity. Interaction in an Urban School. Cambridge University Press, Cambridge.

Rampton, B., 2011. 'From 'Multi-ethnic adolescent heteroglossia' to 'Contemporary urban vernaculars'. Language and Communication 31(4), 276-294.

Rampton, B., 2015. Contemporary urban vernaculars. In Nortier, J., Svendsen, B. A., (Eds.), Language, Youth and Identity in the 21st Century: Linguistic Practices across Urban Spaces. Cambridge University Press, Cambridge, pp. 24-44.

Røyneland, U., 2018. Virtually Norwegian: Negotiating Language and Identity on YouTube. In C Cutler (ed.) Multilingual Youth Practices in Computer Mediated Communication. New York : Cambridge University Press, pp. 145-167.

Said, E.W., 1978. Orientalism. Routledge \& Kegan Paul, London and Henley.

Simpson, P., 2003. On the Discourse of Satire: Towards a Stylistic Model of Satirical Humor. John Benjamins, Amsterdam.

Stroud, C., 2004. Rinkeby Swedish and semilingualism in language ideological debates: A Bourdieuean perspective. Journal of Sociolinguistics 8, 163-230.

Tannen, D. 2001. Power maneuvers or connection maneuvers? Ventriloquizing in family interaction. In Tannen, D., Alatis, J. E. (Eds.), Linguistics, Language and the Real World: Discourse and Beyond. Georgetown University Press, Washington, DC, pp. 50-62.

Ulvenlöv, J., Palm, M., \& Larsson, A., 2017. Utan ånger: Gustaf Ekström - SS-veteranen som grundade Sverigedemokraterna. Eskilstuna: Vaktel förlag.

Wiese, H., 2012. Kiezdeutsch: Ein neuer dialekt entsteht. München: Beck.

Årman, H. 2018. Speaking 'the Other'? Youths' regimentation and policing of contemporary urban vernacular. Language and Communication 58, 47-61.

\section{Transcription conventions:}

((Standard Swedish))

$:$
$:$
$:$

WHAT THE HELL

$?$

$!$ a short pause of less than one second a longer pause, time in seconds comments on linguistic style and/or other contextual information extended sound longer extension said in loud voice indicates question intonation indicates exclamatory intonation 
quotation marks indicate the speaker's reference to someone else's voice.

$(\mathrm{xx})$

inaudible speech

$[---]$

missing speech

\section{FUNDING}

The research upon which this article is based was supported by the Swedish Research Council for Health, Working Life and Welfare (Forte 2014-00873). 